The lack of nursing and ancillary staff contrasts with the proliferation of clerical staff in hospital, group, and board. Some of these staff should now be deflected to caring for patients.-I am, etc.,

Lincoln.

J. H. PrICE.

tions of Ill Committee of Inquiry into AllegaIrregularities at the Ely Hospital, Cardiff, 1969 , Cmnd. 3975. London, H.M.S.O.

\section{Mental Hospitals}

SIR,-It is unfortunate that the conditions in our mental hospitals come to light as a result of fires, which cost the lives of patients, or as the result of inquiries into allegations of cruelty and neglect.

Many of the problems of the subnormality hospital can be traced to the totally inadequate medical staff establishment. Consultant posts are difficult to fill because of a lack of suitable applicants, this in turn being due to the small number of senior registrar training posts in the specialty. There are regions without such posts.-I am, etc.,

\section{Harmston Hall Hospital. \\ Lincoln.}

\section{J. W. GARRY.}

\section{Trichomoniasis and Gonorrhoea}

SIR,-Though Dr. W. Tsao's letter recording the association of gonorrhoea with vaginal trichomoniasis in his area of London (8 March, p. 642) is of considerable interest it must be viewed in perspective. The clinic at the West London Hospital is known and respected for its treatment of vaginitis per se, but the population in which $46 \%$ of patients with trichomoniasis have gonorrhoea is a highly selected group attending a venereal disease clinic. While it is clearly desirable to screen all patients with trichomoniasis for gonorrhoea, the proportion of positives in a gynaecological clinic serving the same area of London is certainly less than $10 \%$ and probably less than $\$ \%$.

The statement in Dr. Tsao's letter that Trichomonas vaginalis is almost always transmitted sexually is not only open to doubt but creates difficulties of interpretation. Parsons and Sommers ${ }^{1}$ quote an incidence of $20 \%$ of trichomonal vaginitis in women isolated from sexual exposure in mental institutions, and mother-daughter transmission is known to occur. ${ }^{2}$ In more than one gynaecological clinic trichomonal infection has been more common in patients attending for the second time than in new patients, until steps were taken to improve clinic hygiene. The danger of Dr. Tsao's statement lies in the direct conclusion that trichomoniasis in a married woman is almost always due to an extramarital excursion undertaken by either husband or wife. Practitioners would do well to consider the potential medico-legal consequences of making such a definite statement.

It is of primary importance in medical practice to treat the patient as well as the disease. For some years it has been my practice to prescribe a ten-day course of treatment for the female partner only and advise her to avoid intercourse for two weeks. This is completely acceptable to the patient with vaginitis, and the implication of sexual transmission, venereal disease, and promiscuity is avoided. In most cases Trichomonas vaginalis has only a limited survival in the male partner, ${ }^{3}$ and in ordinary gynaecological practice recurrence is uncommon if this advice is given. Failure to respond is then certainly no more likely than the figures of between $10 \%$ and $30 \%$ recurrence in the female, which have been reported when the consort also has been given primary treatment. On the few occasions when recurrence is met, detailed explanation and reassurance precede treatment of both patient and consort.-I am, etc.,

$$
\begin{aligned}
& \text { DENIS F. HAWKINS. } \\
& \text { Institute of Obstetrics and } \\
& \text { Gynaecology, } \\
& \text { Hammersmith Hospital, } \\
& \text { London W.12. } \\
& \text { REFERENCES } \\
& \text { ' Parsons, L., and Sommers, S. C., Gynecology, } \\
& \text { 1962, p. S20. Philadelphia, Saunders. } \\
& \text { Trussell, R. E., Trichomonas Vaginalis and } \\
& \text { Trichomoniasis, 1947, p. 106. Springfield. } \\
& \text { Thomas. } \\
& \text { Weston, T. E. T., and Nicol, C. S., British } \\
& \text { fournal of Venereal Diseases, 1963, 39, 251. }
\end{aligned}
$$

\section{Jaundice and Methyldopa}

SIR,-What a pity Drs. R. Wyburn-Mason and C. Anastassiades (22 March, p. 780) did not perform a liver biopsy in their patient. There may have been good reasons for not doing so, but the authors should have given them, since biopsy is essential in patients in whom drug jaundice is suspected if we are to understand the mechanisms. Indeed, I submit that the case report as it stands is valueless and a waste of your space. This is especially so in relation to methyldopa which seems to be associated with a variety of hepatic lesions and is probably a commoner cause of jaundice than the authors suggest, as they might find if they reported their patient's case to the Dunlop Committee.

I have seen one patient with a hepatic reaction, one with cholestatic jaundice, and two with a histological picture that was indistinguishable from that of chronic active hepatitis. The latter finding is particularly interesting in view of the known association of methyldopa with an autoimmune haemolytic diathesis, as shown by a positive Coombs test and with the presence of antinuclear antibody.-I am, etc.,

$$
\begin{aligned}
& \text { Dudley Road Hospital, } \\
& \text { Birmingham 18. }
\end{aligned}
$$

A. Paton.

\section{Pneumatic Splints in Elbow Injuries}

SIR,-A recent case admitted to the accident unit of the Royal National Orthopaedic Hospital at Stanmore has prompted us to write about the use of these splints for immobilization of elbow injuries.

A woman of 49 was admitted an hour after sustaining a fracture dislocation of the right elbow. The elbow had been immobilized in a pneumatic splint which necessitated holding it in the fully extended position. On admission there was clearly vascular insufficiency in the hand, which was colder than the opposite side, and the radial pulse could be returned on flexing the elbow but diminished again on extension.
Although there was no lasting ischaemia resulting from the use of the pneumatic splint in this case, it is felt that it would be wise to warn ambulance crews that the appliance should not be used in the case of elbow injuries.-We are, etc.,

$$
\begin{aligned}
& \text { J. N. WILSON. } \\
& \text { T. ARWYN EVANS. } \\
& \text { Royal National Orthopaedic } \\
& \text { Hospital, } \\
& \text { Stanmore, Middx. }
\end{aligned}
$$

\section{Rejection on Medical Grounds}

SIR,-A large part of the practice of occupational medicine consists in making the kind of decisions about the fitness of an individual for a job which Dr. J. W. Todd (8 March, p. 638) says a doctor cannot make. The doctor is not the sole judge of "capability" (his word, not mine)-of course there are numerous non-medical criteria as well; but if a disability is likely to prevent the proper performance of the work, or be aggravated by it, or render the applicant susceptible to industrial disease, I should have thought it obvious that a doctor is better able to assess its significance than a personnel manager or supervisor. If $\mathrm{Dr}$. Todd had his way, rejections would still occur but be made by laymen.

But should a person be allowed to choose whether to ignore advice that a job might injure his health ? Sometimes this is permissible. Nevertheless, in our industrial society with its welfare state the view that individual illness is a purely personal matter and no concern of anybody else is not tenable. Illness affects the whole community, and there must be limits set to a deliberate running of the risk of contracting it. It costs money to train a new employee to do a job, his absence from it for any reason represents a loss of production, and his illness makes demands on the health service and the social security funds ; he may, moreover, if he contracts an industrial disease through disregard of medical advice, still not be deterred from suing his employer on the grounds that he negligently allowed him to work in employment for which he was unfit. The significance of each factor in the given case, and the ultimate decision, will vary with circumstances, but there are certain jobs for which there are absolute medical contraindications, regardless of the individual's wishes. I have seen, for instance, the almost fatal consequences of the inadvertent exposure of an asthmatic to isocyanates without previous medical examination, and would in no circumstances allow any person so afflicted to undertake work entailing such exposure.

The hypothetical case Dr. Todd cites in his final paragraph would of course be indefensible-but he seems to deduce therefrom as a general proposition that keenness of disappointment at an adverse decision may be taken as a measure of the validity of the reasons on which it is based. Unless this is his intention, I do not see the relevance of the paragraph.-I am, etc.,

\section{F. H. TYRER.}

Rochdale, Lancs. Medical Director,
Rochdale Industrial Health Centre. 